\title{
The globalisation potential of the Russian oil industry: An empirical study*
}

\author{
Sarah E.A. Dixon ${ }^{* *}$
}

A metamodel, derived from the strategic management literature, provided a framework for an eclectic and structured empirical analysis of the globalisation potential of the Russian oil industry and the implications for the international oil industry. A series of interviews were undertaken with senior representatives of Russian and Western oil companies and experts in the field, on the basis of which it was concluded that, despite historical and administrative constraints, there are strong drivers for Russian oil companies to compete globally with the Western oil majors, thereby affecting the international oil game.

Ein aus der Literatur im Bereich Strategisches Management konzipiertes Metamodell versah den Rahmen für eine eklektische und strukturierte Analyse des Globalisationspotentials der russischen Ölindustrie und deren Auswirkungen auf die internationale Ölindustrie. Eine Reihe von Interviews wurde unter Leiter der russischen und westlichen Ölfirmen sowie auch unter Gebietsfachleuten unternommen. Aus diesen Interviews war zu entnehmen, daß russische Ölfirmen dazu getrieben werden, mit westlichen Großfirmen zu konkurrieren und damit einen starken Einfluß auf den globalen Wettbewerb und somit auch eventuell auf das internationale Ölspiel ausüben.

Keywords: Globalisation / strategy / Russia / oil industry / management

\footnotetext{
${ }^{*}$ Manuscript received: 6.5.03, revised: 17.8.03, accepted: 16.10 .03

${ }^{* *}$ Sarah E.A. Dixon, born 1953, Kingston University Business School. Research areas: Strategic processes in transition economies, particularly with reference to Russian oil and petrochemical industry. Corresponding address: Sdixon@dircon.co.uk
} 


\section{Background}

Russia is rated number 3 in the world for oil production (BP 2002). Russia produces almost $1 / 10$ of world oil production and is the second biggest oil exporter after Saudi Arabia (Liuhto/Jumpponen 2003). But the legacy of Soviet mismanagement and the economic collapse after perestroika in the early $90 \mathrm{~s}$ has constrained the development of the industry (Ziener 2001). The 1998 economic crash and the drop in oil prices led to cost cuts and improvements in employee productivity (Gaddy 2000; Russia Review 1998; Snow 1999). This, combined with high oil prices from 2000, generated large cashflows (Brown 2001; Gogek/George 2001). This "bonanza" (Petroleum Economist 2001) opens up new horizons for the oil companies, such as increased investments in the global arena (Brewis 1999; Economist 2001a; Woollen 2001). Simultaneously Western oil companies are targeting Russia to add to their oil reserves (Gaddy 1999; Economist 2000; Economist Intelligence Unit 2000) although progress is limited due to insufficient protection of investors and lack of fiscal flexibility (Ziener 2001).

As Table 1 shows, the Russian oil majors are comparable with their Western counterparts in reserves and production, but they lag on financial indicators and trade at large discounts (74\%) to the oil majors (Gladyshev 2001; Nickolov/Kushnir 2001).

Table 1. Western and Russian Oil Majors Compared (2000) $)^{1}$ (adapted from Nickolov \& Kushnir 2001, Gladyshev 2001, company data

\begin{tabular}{|l|c|c|c|c|c|}
\hline Company & $\begin{array}{l}\text { Mkt Cap (\$ } \\
\text { mln) }\end{array}$ & P/E (x) & EV/Ebitda (x) & Res (mln bbl) & $\begin{array}{l}\text { Prod } \\
\text { bbl) }\end{array}$ \\
\hline Lukoil & 7,347 & 2.7 & 2.1 & 14,202 & 502 \\
\hline Yukos & 8,000 & 2.4 & n.a. & 11,769 & 991 \\
\hline SNG & 10,104 & 3.6 & 1.9 & 9,078 & 278 \\
\hline TNK & n.a. & n.a. & n.a. & 13,313 & 954 \\
\hline Tatneft & 1,074 & 1.4 & 1.3 & 6,135 & 170 \\
\hline Sibneft & 1,327 & 2.3 & 2.0 & 4,599 & 140 \\
\hline ExxonMobil & 296,208 & 17.5 & 8.2 & 15,813 & 1393 \\
\hline Royal Dutch & 128,369 & 15.9 & 7.6 & 10,572 & 709 \\
\hline Shell T\&T & 81,902 & 15.6 & 7.5 & 7,048 & 473 \\
\hline BPAmoco & 195,042 & 13.7 & 7.5 & 12,363 & 1050 \\
\hline $\begin{array}{l}\text { TotalFinaEl } \\
\text { f }\end{array}$ & 103,147 & 14.3 & n.a. & 8,438 & 643 \\
\hline
\end{tabular}

${ }^{1}$ Yukos/Sibneft merger, announced April 2003, has initial combined market capitalisation of $\$ 35$ bln putting it in no. 7 position behind the oil majors. (Jack, A. (2003): Financial Times, 22nd April). 
"The most ambitious Russian majors like to compare themselves with the largest Western oil companies - by size of controlled oil reserves and production - but still cannot boast Western-type management and comparable financial resources" (Khartukov 2001: 6).

\section{Objective of the Research and Conceptual Model}

The objective of the research was to analyse the strategic development of the Russian oil industry in order to assess its globalisation potential and the implications of this for the international oil industry. By globalisation of the Russian oil industry is meant primarily Russian oil companies investing in the global arena, but also Western oil companies coming into Russia.

Figure 1. Metamodel with research questions

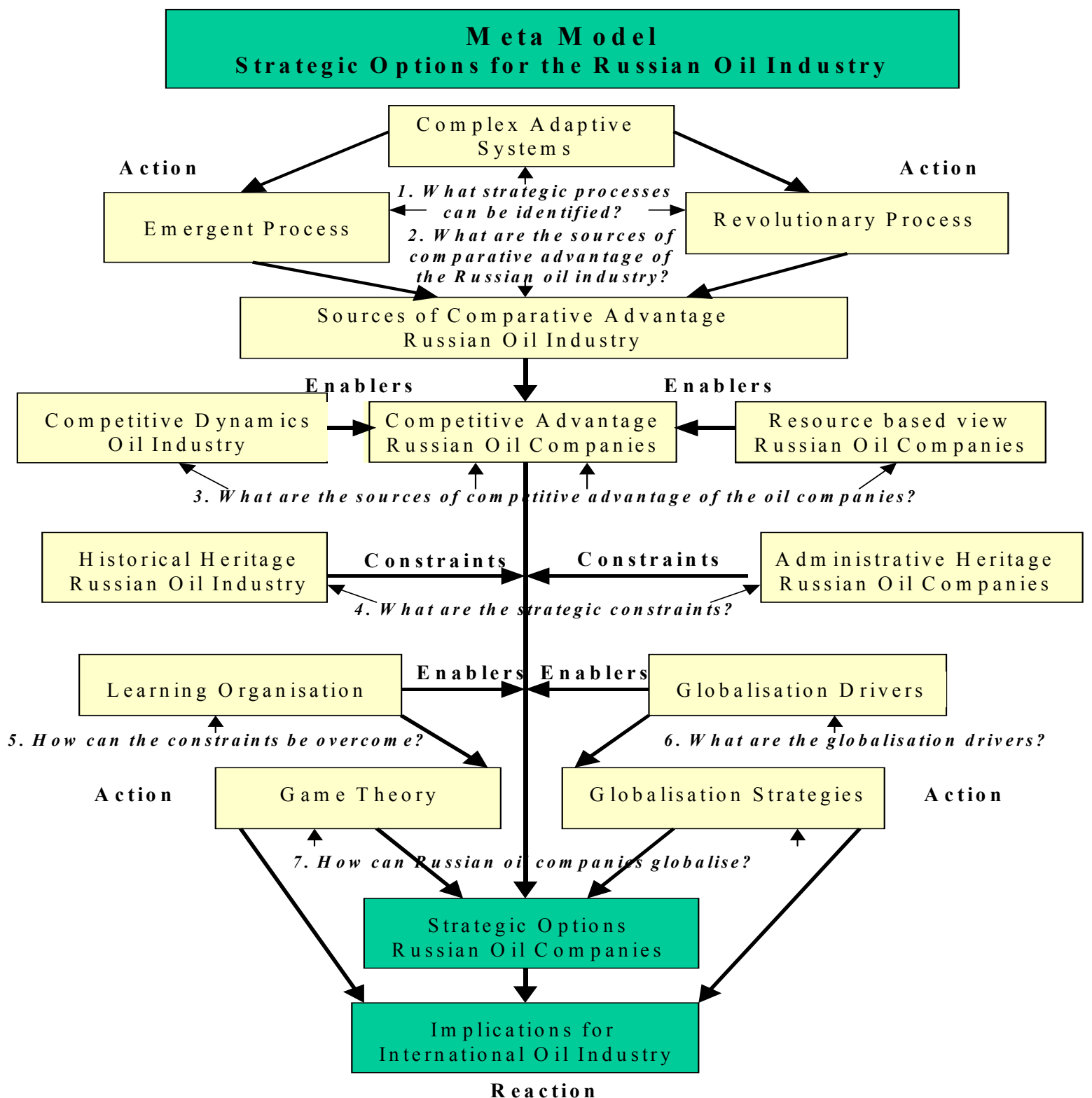


Teece et. al (2000) have pointed out that complex problems benefit from insights from several paradigms. Therefore, given the complexity of this topic, a metamodel (Figure 1) was developed as a framework for a structured and eclectic analysis of the industry and its globalisation potential.

"Complex problems are likely to benefit from insights obtained from all of the paradigms we have identified plus more. The trick is to work out which frameworks are appropriate for the problem at hand. Slavish adherence to one class to the neglect of all others is likely to generate strategic blindspots" (Teece et al. 2000: 310).

The model was grounded in the strategic management literature, drawing largely on Teece et.al (2000) who summarise the major paradigms in strategic management, and Yip (1989) on globalisation. Strategic processes, not covered by Teece et. al. (op.cit), were added to the model. Table 2 shows the paradigms, representative authors, the source, and the link to the metamodel.

Table 2. Strategic paradigms used to develop Metamodel (adapted from Teece 1997: 339)

\begin{tabular}{|c|c|c|c|}
\hline Paradigm & Representative Authors & Source & Metamodel \\
\hline Strategic processes & $\begin{array}{l}\text { Kauffman (1995) } \\
\text { Brown \& Eisenhardt (1998) } \\
\text { Beinhocker }(1997) \\
\text { Gould }(1980 ; 1982) \\
\text { Hamel }(1996 ; 2000) \\
\text { Schumpeter }(1961) \\
\text { Zohar (1997) }\end{array}$ & $\begin{array}{l}\text { Author' } \\
\text { s own }\end{array}$ & $\begin{array}{l}\text { Complex } \\
\text { adaptive systems } \\
\text { Emergent } \\
\text { process } \\
\text { Revolutionary } \\
\text { process }\end{array}$ \\
\hline Competitive forces & Porter $(1980)$ & Teece & $\begin{array}{l}\text { Competitive } \\
\text { dynamics } \\
\text { Competitive } \\
\text { advantage }\end{array}$ \\
\hline Resource based & Teece $(1980 ; 1982)$ & Teece & Resource based \\
\hline Dynamic capabilities & $\begin{array}{l}\text { Teece, Pisano \& Shuen (2000) } \\
\text { Dosi, Nelson \& Winter (2000) } \\
\text { Prahalad \& Hamel (1990) } \\
\text { Porter (1990) } \\
\text { Dierickx \& Cool (1989) }\end{array}$ & Teece & $\begin{array}{l}\text { Historical } \\
\text { heritage } \\
\text { Administrative } \\
\text { heritage } \\
\text { Organisational } \\
\text { learning } \\
\text { Comparative } \\
\text { advantage }\end{array}$ \\
\hline Globalisation & $\begin{array}{l}\text { Yip (1989; 1992) } \\
\text { Bartlett \& Ghoshal (1989) }\end{array}$ & Yip & $\begin{array}{l}\text { Globalisation } \\
\text { drivers } \\
\text { Globalisation } \\
\text { strategies }\end{array}$ \\
\hline Strategic conflict & $\begin{array}{l}\text { Brandenburger \& Nalebuff (1995; } \\
\text { 1996) }\end{array}$ & Teece & Game theory \\
\hline
\end{tabular}


The metamodel has the following logic. The first stage of the analysis is based on complex adaptive systems since the Russian oil industry interacts with different elements and environmental influences in the domestic and global arena. This gives rise to strategic processes which may be either revolutionary or emergent in nature. The next part looks at sources of comparative and competitive advantage arising both from a market positioning and a resource based viewpoint. These are the enablers of strategy. However, path dependency puts historical and administrative constraints on strategy development. These constraints can be overcome by the development of a learning organisation another enabler of strategy. Furthermore, in the global context, there are globalisation drivers which are also enablers of strategy. The globalisation strategies adopted in response to the drivers form part of the game played in the international arena and have implications for the international oil companies. This eclectic approach to the strategic analysis of the Russian oil industry enables a comprehensive understanding of its context and capabilities, which in turn provides the grounds for the conclusions made about the globalisation potential of the Russian oil industry and the implications for the international oil industry.

\section{Research Methodology}

Whilst the conceptual framework provided by the metamodel inclines towards a nomothetic approach, the primary research took an interpretivist stance, with the goal of understanding (Verstehen) the "meaning" of social and business phenomena (Schwandt 1998). This "paradigm crossing" (Schultz/Hatch 1996) recognises different levels of understanding in complex organisational studies. The literature review, using Russian and English sources, placed the Russian oil industry in the context of major theories of strategic management. This analysis formed the basis for the primary research questions (Appendix 1).The primary research involved cross-sectional qualitative analysis with the consultation of experts. Semi-structured personal interviews enabled in-depth understanding. The resulting analysis and conclusions thus represent a distillation of strategic thinking on the Russian oil industry. Samples were taken from four segments within the oil industry: Western/Russian oil companies and Western/Russian analysts (Appendix 2). The "analysts" included representatives of financial and audit institutions, energy research organisations and consultancies, a press correspondent and a scenarios expert. The target respondents in the oil companies were senior managers responsible for strategy, investor relations or corporate affairs. 23 interviews were conducted in English or Russian according to the preference of the respondent. 19 interviews were face to face, of which 15 were in Moscow and 4 in London, and 4 interviews were conducted by telephone. Each interview was targeted at one hour. All the companies approached granted an interview and the number of interviews was within the 
norms for an interpretivist approach. The reliability of the data was assessed against the criteria of holistic fallacy, elite bias and going native (Miles/Huberman 1994). Due attention to clustering and noting themes and patterns served to mitigate against holistic fallacy. All informants were articulate and high status thus reducing elite bias. The highest risk was "going native" due to the researcher's long background in the Russian market. This was mitigated by the predominance of Western commentators in the respondent sample. This work is assumed to have the requisite validity due to the knowledge and expertise of the interviewees.

\section{Analysis}

The structure of the analysis section is based on the strategic paradigms identified in Table 2.

\section{Strategic Processes}

All interviewees regarded the recent development of the Russian oil industry as revolutionary (Hamel 1996, 2000) rather than emergent (Lindblom 1959; 1968; Mintzberg 1979; Mintzberg et al. 1998; Nelson/Winter 1982; Quinn 1980). The speed and scope of change is acknowledged by all interviewees. The privatisation and the post 1998 changes were revolutionary processes quantum leaps to another configuration, as described by Miller and Friesen (1984). This is illustrated in Figure 2 as changes in strategic trajectory. This process does not, however, represent Hamel's business concept innovation (2000), because Russian companies are catching up - revolutionising themselves, but not creating anything new.

"They're a decade away as they consolidate and go through all the revolutionary changes that for them are revolutionary, that will change them into globalised international companies"

\section{Western Analyst}

"Transform or revolutionise in the short term? Absolutely, we're doing that right now. Increased transparency, Western management techniques, enterprise management systems, there are a lot of things that we can do to make a very strong difference in the way we do business." (Russian Oil Company).

\section{Competitive Forces}

Russian oil companies can leverage their comparative and competitive advantage to shift trajectory. Their main sources of comparative advantage are their oil reserves, as well as high calibre people, the existence of a mature oil industry and an "oil culture." 
"If Russian companies can compete in anything, it is their intellectual potential. In actual fact, Russians very quickly learnt the rules of the game in the market" (Russian Analyst).

"I think the Russians are very clever people and the way they keep things operating out in these harsh conditions is an absolute credit to them" (Western Analyst).

Figure 2. Strategic trajectories for Russian oil companies

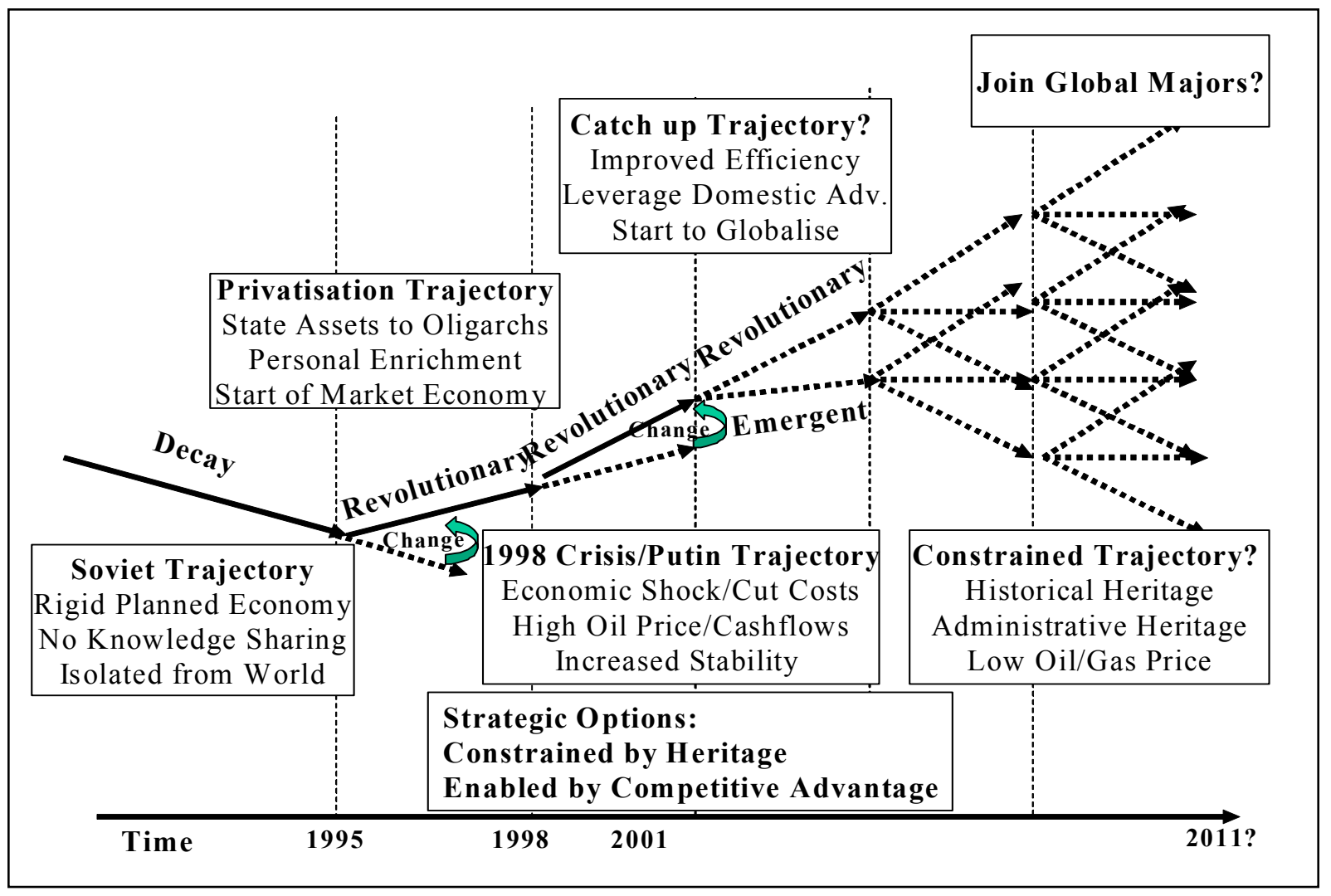

However, using Porter's definition of the competitive advantage of a nation (1990), Russia lags due to the lack of a supporting network, low knowledge sharing and restricted competition (the oil oligarchs have separate fiefdoms). But the oil industry is cash rich, so some of these constraints can be overcome by acquisition e.g. technology and expertise.

Throughout the world oil is a political issue. In Russia the state establishes the rules of the game for the oil companies in the form of taxes, export quotas, internal crude supply obligations etc.

"Making money in energy is working in ways that grant you regulatory permission to make money - it's not about finding oil, it's finding permission to drill for oil." Western Analyst

"The competitiveness of Russian oil is determined to a great extent by government policy" (Russian Oil Company). 
However, there are mixed views about the relative power of the state versus the oil companies. The Russian oil companies see the role of the state in their business as diminishing, as well as their influence on government as decreasing. ${ }^{2}$

"Sooner or later everything will be done in the interests of those who have the real economic power - not the government, not the president, not Parliament. The Government has to do what is necessary for the oil companies" (Russian Analyst).

"The current leadership of Russia has indicated that it would like business to do business rather than attempt to run the country or make policy decisions" (Russian Oil Company).

The more stable political situation promotes economic growth and fiscal reform, strengthening the competitiveness of the oil industry. The Russian oil companies are subject to only moderate competitive forces in their domestic industry, where they have a strong established position. In their domestic market Russian companies feel no threat from Western companies: they can buy in technology, expertise and management skills, they know Russian ways of doing business, they have adequate finance, access to reserves and political influence:

"There are no real advantages that Western companies could have in Russia" (Russian Oil Company).

"Their way of business is founded on personal contacts. These are not the traditional ways of Western companies i.e. the Russian companies have an enormous competitive advantage in Russia, but one which cannot be easily applied in other countries" (Western Oil Company).

Other sources of competitive advantage are the low cost structure of the upstream oil business and the low exploration risk due to the huge size of proven reserves. However in the global arena Russian oil companies lack access to the capital markets, have little experience of project management and lack management skills. Here they are subject to strong competitive forces and they have a weak competitive position vis à vis their Western oil companies. Intensity of rivalry in the international oil arena is high and the Western oil majors are well ensconced - they have decades of experience as multinationals and can leverage learning from one area to another. Russian oil companies not only lose out to their Western counterparts in learning, but also in their ability to attract finance for growth via the stock market. In certain areas, however, they can compete, such as the areas of former Soviet influence, areas with

\footnotetext{
${ }^{2}$ The state prosecutor's investigations into the activities of the Russian oil companies Yukos and Sibneft are evidence of the ongoing topicality of this issue (July 2003)
} 
outstanding debts to the Soviet Union, which can be offset against concessions, and areas which are politically off-limits to Western oil companies.

\section{Resource-Based}

The resource-based school of strategy provides insights into firm resources and capabilities, and their development and deployment to take advantage of market opportunities (Uhlenbruck et al. 2003). The resource based analysis of the Russian oil industry demonstrates the benefits of existing infrastructure and a good reserves/production base, but the disadvantages of poor managerial and organisational processes, poor technology, lack of access to international capital, lack of experience, limited project management skills and lack of responsiveness to stakeholder needs. Most Western companies believe that the Russian companies differ radically from their Western counterparts with respect to efficiency, flexibility, decision making, team working, innovation and information sharing. Historical and administrative constraints represent the "stickiness" described by Teece et. al.(2000), whereby companies in the short term are stuck with what they have inherited. The Russian oil industry has a 70 year heritage of a planned economy and exhibits change inhibiting characteristics listed by Kanter (1989), such as elaborate hierarchies and slow decision making. However many of the perceived characteristics of Russians, such as corruption, laziness, information sequestration, blame culture and hierarchies are not necessarily innate characteristics but an inheritance of the Soviet system:

"Russians are not thieves. Russians are not bureaucrats by nature. It is just that the previous Soviet period makes them traditionally do what was the norm in this country" (Russian Analyst).

"The country is organised on a completely different basis. This is not linked with the particularities of the Russian character, the genetic predisposition of Russians to certain types of activities. But it is a completely different country, there is a completely different relationship between power and business, and Western companies are totally unable to understand these relationships" (Russian Analyst).

As a result of this heritage, cut off from the world for 70 years, there is a huge amount of suspicion on both sides.

"In the State Duma there are still people who think that Western firms are imperialists: sharks, come to plunder the Motherland" (Russian Analyst).

"These companies exist within a country and they cannot become western companies within the Russia that we have today. It will take huge political and economic transformation" (Western Analyst). 
According to path dependency theory, a firm's history constrains its future behaviour and choice may become locked-in (Arthur 1984; Bercovitz et al. 2000; Teece et al. 2000). Although history matters, there can be "perturbations at critical times" (Gould 1980, 1982) which influence outcomes. Two such perturbations were the privatisation process, and the 1998 economic crisis with a subsequent high world oil price, which tilted the economy into further new structures and patterns (see Figure 2). Thus the "phase-locking" was destroyed in a process of punctuated equilibrium (ibid). External impetus caused a shift in trajectory which was magnified by the internal resources of the companies - the internal levers for change such as adopting Western management skills, more focused strategy, financial control and capex discipline. Future business trajectories will depend both on external stimuli, such as movements in the oil price, and on the development of the internal resources of the firm.

Figure 3. Constraints and enablers of strategy

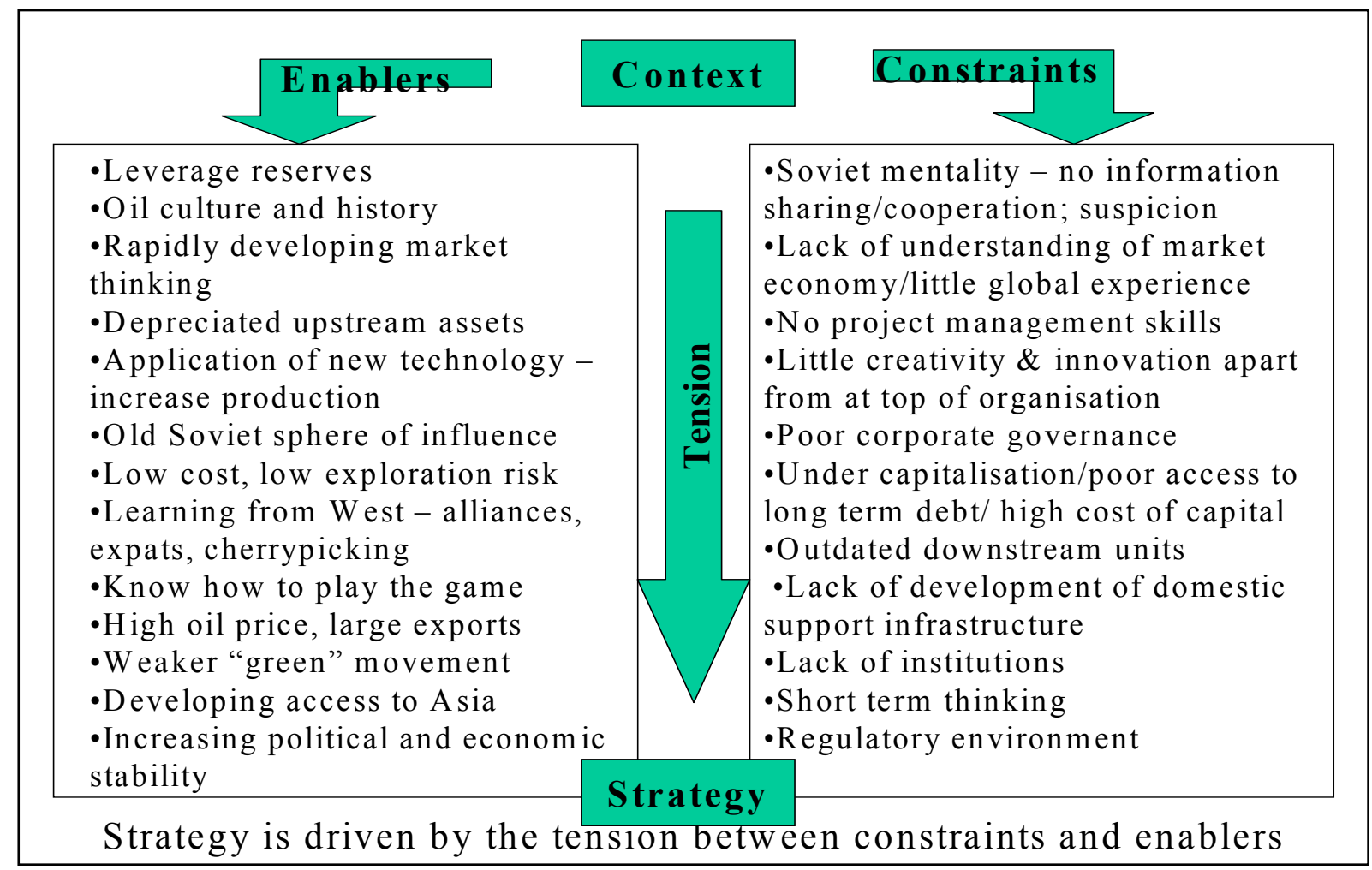

Strategy is driven by the tension between enablers of strategy, or sources of competitive advantage, and strategic constraints (Wilson 2002). The constraints and enablers of strategy for Russian oil companies, as described by the interviewees, are illustrated in Figure 3. What are perceived as constraints for a Western oil company, such as accountability to stakeholders, corporate governance, keeping to the rules of the game and attention to environmental issues, are paid less attention by Russian companies, particularly in the domestic context. Thus Russian businessmen are characterised as extremely aggressive. 


\section{Dynamic Capabilities}

The increased efficiency of the Russian oil companies has been a function of changes in organisational structure and top management, and the introduction of Western management techniques throughout the company. The importance of empowerment and decentralised decision-making in a complex system is emphasised by Western oil companies. However Russian oil companies believe strict management control is needed at this stage:

"The first thing to do is to stop the leakage, sloppiness, the bad business practice of the past You need the old managers in place, you can't replace them all, and they're very good technically, but some of them just don't have the financial or the managerial understanding to work in the new system, and some of their interests aren't completely aligned with our shareholders, and therefore we go for centralised management" (Russian Oil Company).

"The first trick is rigid centralisation, strict control of cash flows, transparency in operations, and beginning to top-down drive international management techniques through the company" (Russian Oil Company).

In this initial stage of development the dynamic capabilities of the organisation will therefore be a function of the capabilities of the top management.

Organisational learning is a major lever for change (Lampel 1998; Senge 1990; Thurbin 1997). Russian oil companies lack global reach and are therefore restricted in the development and transfer of knowledge compared to Western companies. Knowledge sharing was not encouraged in Soviet times and major cultural change is needed for Russian companies to develop their learning capacity. The transformation from control to flexibility, distrust to trust, and bureaucracy to organic organisation, is not easy, but significant progress has been made, particularly in marketing and financial functions (Sagers 1997). Russian companies have adopted various methods of learning from the West, ranging from the employment of expatriates and encouragement of business management training, to the establishment of alliances/joint ventures and acquisition of overseas assets. The learning curve is steep, but they catch up quickly, and cherry pick the best of Western practices without taking the baggage.

"It's probably where a Western oil company was in the 1960s. But it knows the paths to go down so it won't take 40 years to get to where the industry is today" (Western Analyst).

On the other hand, some Western analysts think they will never catch up:

"They're a couple of decades behind. They look at where Shell and BP and Exxon Mobil are and they're trying to create that, but they don't realise those guys have moved on and they're doing something else now" (Western Analyst). 


\section{Globalisation}

Globalisation drivers have been variously described by (Yip 1992, Bartlett/Ghoshal (1989), Micklethwait/Wooldridge 2000). For the Russian oil industry the drivers include spreading portfolio risk, access to learning and experience, more certain economic conditions and payment, enhanced ability to raise capital, securing a downstream market for crude oil, high cashflows from domestic operations providing resources for foreign investments and ego.

"For companies like Lukoil, having an international profile suits them in terms of comparison with its peers, and in the enhanced ability to raise capital international projects bring" (Woollen 2001: 43).

Russian companies consider it is only a matter of time before they can compete on an equal footing. However, the global position of the oil majors has been built up over 150 years. Most Western interviewees believe that Russian oil companies cannot compete on a par with Western companies on a global basis:

"What do they offer that Western companies do not offer, and where would they get the money to fund it from? I don't see them competing until they can become more efficient, more transparent. It's going to cost them more money to do the same things" (Western Oil Company).

"Why do I not think they're going to be able to compete? One management, two technology, and three capital and that's really what international oil companies are all about" (Western Analyst).

A contrary view is expressed by another Western analyst:

“I think they've learned a lot of lessons, they've come a hell of a long way in a very short time, they're very aggressive, very astute, and they have leverage in a number of regions".

There is thus disagreement on whether the Russian oil companies will be able to compete in global markets on a par with the Western oil majors - the Western oil companies and Western analysts mostly took a negative stance, whereas the Russian oil companies were positive. ${ }^{3}$ All interviewees considered that the Russian oil industry would continue to globalise - the disagreement was as to speed, and scope. All were agreed on the major constraints of lack of access to international finance and lack of management skills.

The Russian oil companies may have a long way to go to become the transnational organisations described by Bartlett/Ghoshal (1989), but powerfully in their favour is the leverage they have over Western oil companies in terms of offering access to their reserves in exchange for positions in the global market. The globalisation strategies of the Russian oil companies can be

\footnotetext{
${ }^{3}$ The Yukos/Sibneft merger announced in April 2003 will bring them into No. 7 position by market capitalisation compared to the Western oil majors
} 
categorised as follows: focus on areas where they feel comfortable and understand the risks (areas of former Soviet influence); move into the downstream in the CIS and East Europe (adding value to crude); asset swapping; international partnership (gives access to the experience of Western partners); "wild cards" (e.g. the Getty Oil acquisition by Lukoil for learning and "ego")

Most interviewees believed that the Russian oil companies would be best served by participating in international projects as a joint venture partner, thus enabling learning from the Western partner and risk sharing. All interviewees can conceive of mergers and acquisitions involving Western oil companies in the medium term, maybe even in 2-3 years. The stakes are high - Russia offers access to oil production and reserves, and the West offers access to global markets.

"I see the Russian oil industry emerging (as) part of the global industry. But Russia is always going to be a special case, in which it's going to be easier for the Russian oil companies to go out than for other companies to come in" (Western Analyst).

\section{Strategic conflict}

The Russian oil industry is increasingly interacting with the rest of the world and with the Western oil companies. Little of what is happening in the Russian oil industry is happening in isolation. The Heisenberg principle in game theory, whereby the game is changed when you join it (Nalebuff/Brandenburger 1996), applies to the Russian oil industry in the international context. The game has been changed, not only in terms of Russia's increasing ability to compete in the world market, but also in the context of the opportunities for Western companies in Russia. Access to new reserves is a driving force for international oil companies. The extent to which these opportunities can be developed to mutual advantage will depend on whether a confrontational (win/lose) or a cooperative (win/win) stance is adopted by the parties. Both sides have a huge amount to gain - access to the global market, or access to Russian oil production and reserves. Primary research has highlighted the win/lose attitude of the Russians, and, to a degree, of the Western oil companies in Russia.

"I think the pie is big enough for everyone to get a reasonable share but sometimes the Russian mentality is just a zero sum game. So if we get something that moves ahead, then that means that they have lost something somehow, even if it wouldn't have been a project that they'd have done" (Western Oil Company).

"A lot of foreign companies came in here with a bit of greed, thinking these Soviets won't know anything about Western practices and we can rip them off 
nicely. But the westerners who thought that this was easy pickings, at the end of the day had a rude awakening" (Western Analyst).

With a maturing of relationships and a better mutual understanding it seems likely that both sides will coalesce towards a win/win situation and the concept of coopetition (Nalebuff/Brandenburger 1996).

"Russian companies are now moving away from the win/lose model of confrontation, culture of theft - if I'm sitting down and negotiating something with you basically I want to steal something from you - to understanding that it can be a win/win" (Western Oil Company).

\section{Table 3. Conclusions of strategic analysis}

\begin{tabular}{|c|c|}
\hline $\begin{array}{l}\text { Strategic } \\
\text { Processes }\end{array}$ & $\begin{array}{l}\text { Change has been radical (revolutionary) for the Russian oil industry, but it still } \\
\text { lags Western cos. }\end{array}$ \\
\hline $\begin{array}{l}\text { Compet- } \\
\text { itive } \\
\text { Forces }\end{array}$ & $\begin{array}{l}\text { Oil and intellectual capability provide comparative advantage, but otherwise lag } \\
\text { in national competitiveness. } \\
\text { Close links between politics and oil - interaction between government and oil } \\
\text { industry yet to mature. } \\
\text { Competitive advantage in domestic market and in former Soviet sphere of } \\
\text { influence, but lag in international arena (lack management skills, \& access to } \\
\text { capital /learning). }\end{array}$ \\
\hline & $\begin{array}{l}\text { Existing infrastructure/production base but lack managerial expertise and } \\
\text { technology. } \\
\text { Historical heritage of planned economy inhibits change. } \\
\text { Path dependency interrupted by external stimuli (privatisation/economic } \\
\text { crisis/high oil price). } \\
\text { Change in strategic trajectory reinforced by development of organisational } \\
\text { capability. }\end{array}$ \\
\hline $\begin{array}{l}\text { Dynamic } \\
\text { Capa- } \\
\text { bilities }\end{array}$ & $\begin{array}{l}\text { Rigid centralised control required to inculcate Western management practices. } \\
\text { Dynamic capabilities dependent on top management } \\
\text { Steep learning curve, but Western companies dispute whether Russian oil } \\
\text { companies will ever catch up. }\end{array}$ \\
\hline & $\begin{array}{l}\text { Strong globalisation drivers for Russian oil industry: spread portfolio risk, } \\
\text { learning, access to capital, securing downstream market, high cashflows and ego. } \\
\text { Russian companies are bullish about joining top rank oil companies, but Western } \\
\text { companies discount this in the short/medium term. } \\
\text { Globalisation strategies may be to focus on areas where they have competitive } \\
\text { advantage or to enter alliances with Western companies. }\end{array}$ \\
\hline & $\begin{array}{l}\text { International oil game is changed by the global ambitions of the Russian oil } \\
\text { companies. } \\
\text { In play on the one side is access to Russian oil production/reserves and on the } \\
\text { other side access to the global market. } \\
\text { Former win/lose attitudes on both sides are maturing towards win/win and } \\
\text { coopetition. }\end{array}$ \\
\hline
\end{tabular}




\section{Conclusions}

\section{Strategic Analysis}

The main conclusions of the strategic analysis of the Russian oil industry are summarised in Table 3.

\section{Globalisation Potential and Implications for the Western Oil Majors}

The objective of this study was to assess the globalisation potential of the Russian oil industry and the implications for the Western oil majors. As the analysis has shown there is strong evidence showing that Russian oil companies are catching up rapidly with their Western counterparts. Many of the Russian oil companies have serious ambitions to compete in the global arena, not just in their traditional area of crude oil exports, but as fully fledged international operators with investments in both upstream and downstream activities outside their domestic market. The strategic analysis has demonstrated that the Russian oil companies have significant sources of competitive advantage, particularly in the domestic arena.

The pace of internal organisational change and of development of Western managerial skills is such that their ambitions in the global arena are no longer just wishful thinking. Western oil companies may be underestimating the capabilities of the Russian oil industry and overestimating the risks and constraints of the Russian business environment. Equally, however, in the context of the ongoing consolidation of the international oil industry, the Russian oil companies may be overestimating their abilities to become major global players - their cashflow and their fortunes are heavily reliant on a high oil price in the export market and on continuing political stability, and the Western oil majors have strongly entrenched positions.

The learning process should lead to improved understanding of the benefits of "coopetition" and "win/win" relationships with Western partners, rather than "win/lose." This will stimulate the globalisation process, since international operations are characterised by joint ventures, consortia and alliances. The changes in the Russian oil industry will affect the international oil game. Western companies will see a new competitor in the global arena, but will also have increasing opportunities to participate in the Russian domestic oil industry.

The "globalisation" of the Russian oil industry is regarded as a feasible option via the following routes: focus on areas where they have competitive advantage e.g. old Soviet sphere of influence; strategic international additions to the downstream value chain; participation in international consortia, initially as a junior partner, in order to acquire learning; leveraging domestic reserves and production assets to secure positions abroad i.e. allowing Western oil 
companies increased access to the Russian oil industry; merger with, or acquisition by, a Western oil company. ${ }^{4}$

Given the strategic constraints upon the Russian oil industry, the strong entrenched positions of the international oil majors and the powerful forces for consolidation of the global oil industry, it is not regarded as feasible for a Russian oil company on its own to compete globally on a par with the Western oil majors. ${ }^{5}$ The pressures that dictated the oil megamergers (Economist 2001b) are likely to lead to a merger between a Russian oil company either with an existing international oil major ${ }^{4}$, or with a second rank international oil company thus creating a new international oil major. This offers a means for a second rank global oil company, albeit high risk, of moving up into the top rank of the oil majors.

Further research might investigate how the organisational transformation of the Russian oil companies could be leveraged to other parts of the Russian economy. The Russian government would be foolish to ignore the real progress that has been made by these companies in developing efficient and effective organisations which are on a trajectory to catch up with their Western counterparts. The state prosecutor's investigation into Yukos' affairs in July 2003 is having a destabilising effect on the Russian oil industry and the Russian economy. Referring back to Figure 2, there is a real danger that developments might be constrained not only by a potential fall in the oil price, but also by the re-imposition of significant administrative and political constraints. The strategic trajectory for the Russian oil industry would not then be one of catching up with the global majors and of manifestation of national pride and strength, but a fall back into decline and isolation. A deterioration in the political relationships of the Russian oil industry will adversely affect both inward and outward investment

\section{Acknowledgements}

I would like to acknowledge with thanks the contribution of my research supervisor, Prof Robin Matthews, Professor of International Business Policy at Kingston University Business School.

\footnotetext{
${ }^{4}$ A 50/50 joint venture was announced 27th June 2003 between BP and TNK.

${ }^{5}$ The Yukos/Sibneft merger announced on 22nd April 2003 moved the company into No. 7 position behind the Western oil majors, but political/legal issues are currently constraining development.
} 


\section{References}

Arthur, W.B. (1984): Increasing Returns and Path Dependence in the Economy. University of Michigan Press.

Bartlett, C./Ghoshal, S. (1989): Managing Across Borders: The Transnational Solution. Harvard Business School Press, Boston.

Beinhocker, E.D. (1997): Strategy at the Edge of Chaos, in: The McKinsey Quarterly, No. 1, pp 109-118

Bercovitz, J.E.L./De Figueredo, J.M., et al. (2000): Firm Capabilities and Managerial Decision Making: A Theory of Innovation Biases, in: Shapira, Z. (ed.): Technological Oversight and Foresight. Cambridge University Press, Cambridge.

BP (2002): The Statistical Review of World Energy 2001. BP, London.

Brandenburger, A.M./Nalebuff, B.J. (1995): The Right Game: Use Game Theory to Shape Strategy. In: Harvard Business Review, No. 73, pp 57-71.

Brewis, J. (1999): Investors Begin to Look to Eastern Europe Again. in: Corporate Finance, June 1999, pp 20-22.

Brown, C. (2001): Russian Oil Companies Gear Up for Expansion into the West. European Downstream Oil Report. Wood Mackenzie, London.

Brown, S.L./Eisenhardt, K.M. (1998): Competing on the Edge: Strategy as Structure Chaos. Harvard Business School Press, Boston, MA.

Comrade Capitalist/ Russia's Overseas Investment, in: Economist, Feb 17, 2001, pp 95.

Dierickx, I./Cool, K. (1989): Asset Stock Accumulation and sustainability of Competitive Advantage. In: Management Science, No. 35, pp 1504-1511.

Dosi, G./Nelson, R.R., et al. (2000): The Nature and Dynamics of Organisational Capabilities. Oxford University Press, New York.

Gaddy, D.E. (1999): Russian Oil Major Yukos Implements Western-Style Reorganisation. In: Oil \& Gas Journal, Tulsa, No. 97, Jun 14, pp 21-25.

Gaddy, D.E. (2000): Fresh Opportunities Arise in Russia as Country's Oil Majors Respond to Lessons Learned from the 1990s, in: Oil and Gas Journal, No. 98, Feb 28, pp 23-26.

Gladyshev, A. (2001): Investor Meetings September. Yukos.

Gogek, D./George, L. (2001): Exports: Russia Prefers High Tax to Economic Success, in: The Russia Journal, No. 4, July, pp 20-26.

Gould, S.J. (1980): The Panda's Thumb. W.W.Norton, New York.

Gould, S.J. (1982): Free to be Extinct. In: Natural History, Aug 1982, pp 12-16.

Hamel, G. (1996): Strategy as Revolution. In: Harvard Business Review, July-Aug 1996, pp 69-82.

Hamel, G. (2000): Leading the Revolution. Harvard Business School Press, Boston, MA.

Kanter, R.M. (1989): When Giants Learn to Dance: Mastering the Challenges of Strategy. Simon \& Schuster, London.

Kauffman, S.A. (1995): At Home in the Universe. the Search for Laws of Self-Organization and Complexity. Viking, London. 
Khartukov, E.M. (2001): Russia: Oil Companies, Privatisations, Alliances \& Overseas Ventures. International Center for Petroleum Business Studies, Moscow.

Lampel, J. (1998): Towards the Learning Organisation. In: Mintzberg, H.,Ahlstrand, B., et al. (ed.): Strategy Safari, pp 214-215.

Lindblom, C.E. (1959): The Science of Muddling Through. In: Public Administration Review, No. 19 , pp 79-88.

Lindblom, C.E. (1968): The Policy Making Process. Prentice Hall, Englewood Cliffs NJ.

Liuhto, K./Jumpponen, J. (2003): The Russian Eagle has Landed Abroad. Department of Industrial Engineering and Management, Lappeenranta University of Technology.

Micklethwait, J./Wooldridge, A. (2000): Future Perfect: The Hidden Promise of Globalisation. William Heinemann, London.

Miles, M.B./Huberman, A.M. (1994): Qualitative Data Analysis: An Expanded Sourcebook. Sage, London.

Miller, D./Friesen, P.H. (1984): Organisations: A Quantum View. Prentice Hall, Englewood Cliffs, NJ.

Mintzberg, H. (1979): An Emerging Strategy of "Direct" Research. In: Administrative Science Quarterly, No. 24, December 1979.

Mintzberg, H./Ahlstrand, B., et al. (1998): Strategy Safari. Prentice Hall, Hemel Hempstead.

Nalebuff, B.J./Brandenburger, A.M. (1996): Coopetition. Harper Collins Business.

Nelson, R.R./Winter, S.G. (1982): An Evolutionary Theory of Economic Change. Harvard University Press, Boston.

Nickolov, R./Kushnir, P. (2001): Russian Oil Sector. ABN-AMRO Oil and Gas Sector Research. ABN-AMRO.

Oil and the New Economy (2000), in: Economist.

Oil Industry Enjoying Bonanza (2001), in: Petroleum Economist, pp 37.

Porter, M. (1990): The Competitive Advantage of Nations. In: Harvard Business Review, Mar-Apr 1990

Prahalad, C.K./Hamel, G. (1990): The Core Competence of the Corporation, in: Harvard Business Review, No. 68, pp 79-91.

Quinn, J.B. (1980): Strategies for Change: Logical Incrementalism. Irwin, Homewood.

Russia: Pushing or Pulling FDI? Country Monitor (2000), in: Economist Intelligence Unit.

Russia Review (1998): Russia's Dilemma: Have Oil, Can't Sell, Aug 14 1998, pp 22-25.

Sagers, M.J. (1997): Prospects and Possibilities in Russian-American Economic Relations: Cooperation and Competition Between American and Russian Corporations. Russian American Business Leaders Forum, Moscow.

Schultz, M./Hatch, M.J. (1996): Living with Multiple Paradigms: The Case of Paradigm Interplay in Organisational Culture Studies, in: Academy of Management Review, No. 21, pp 529-557.

Schumpeter, J. (1961): The Theory of Economic Development. Harvard University Press, Cambridge, MA. 
Schwandt, T.A. (1998): Constructivist, Interpretivist Approaches to Human Inquiry. In: Denzin, N.K.,Lincoln, Y.S. (eds) The Landscape of Qualitative Research. Theories and Issues, No. I. Sage, Thousand Oaks.

Senge, P.M. (1990): The Fifth Discipline: The Art and Practice of the Learning Organisation. Doubleday, New York.

The Slumbering Giants Awake (2001b), in: Economist, Feb 82001.

Snow, N. (1999): Russia's Failure to Tackle Problems Makes Oil, Gas Outlook Bleak, in: Oil and Gas Investor, Jan 1999, pp 15-17.

Teece, D.J. (1980): Economics of Scope and The Scope of the Enterprise, in: Journal of Economic Behavior and Organization, No. 1, pp 223-247.

Teece, D.J. (1982): Towards an Economic Theory of the Multiproduct Firm, in: Journal of Economic Behavior and Organization, No. 3, pp 39-63.

Teece, D.J./Pisano, G., et al. (2000): Dynamic Capabilities and Strategic Management, in: Dosi, G.,Nelson, R.R., et al. (ed.): The Nature and Dynamics of Organisational Capabilities. Oxford University Press, New York.

Thurbin, P.J. (1997): Organisational Learning and Entrepreneurship, in: Evans, R./Mador, M., et al. (ed.): Strategic Management II. Kingston University, Kingston upon Thames.

Uhlenbruck, K.,Meyer, K.E., et al. (2003): Organizational Transformation in Transition Economies: Resource-based and Organizational Learning Perspectives, in: Journal of Management Studies, No. 40, March 01, 2003, pp 257-282.

Wilson, N. (2002): Strategic Management II. MBA Lecture, Kingston University.

Woollen, I. (2001): Internationalisation - Russians Abroad. Russia Upstream Report. Wood Mackenzie, Edinburgh.

Yip, G.S. (1989): Global Strategy...In a World of Nations?, in: Sloan Management Review, No. 31, Fall89, pp 29.

Yip, G.S. (1992): Total Global Strategy: Managing for Worldwide Competitive Advantage. Prentice Hall.

Ziener, G. (2001): The Russian Oil Sector: Finally Ready for Investors?, in: Russian Economic Trends, No. 10, Dec2001, pp 38.

Zohar, D. (1997): Rewiring the Corporate Brain. Berrett-Koehler Publishers Inc, New York. 


\section{Appendix 1 List of Interview Questions with Prompts}

1) To what extent can you envisage Russian oil companies competing with the international oil majors in the world arena?

Prompts: Lukoil - Getty Oil, TNK - East Europe, Kuwait - European Downstream

2) What factors about the Russian oil industry inhibit it from becoming a major global player?

Prompts: Inefficiency, lack of capital, culture, historical/ administrative constraints.

3) Do you think that the Russian oil industry can transform/revolutionise itself in the short to medium term?

Prompts: Emergent vs. revolutionary, path dependency vs punctuated equilibrium

4) What do you believe are the major sources of competitive advantage for the Russian oil companies?

Prompts: Not just access to natural resources. What else?

5) How could Russian oil companies improve their performance?

Prompts: Learning organisation, interaction with West, quality programmes, BPR

6) To what extent can Russian oil companies manage the need to balance structure versus flexibility, efficiency versus innovation?

Prompts: Complex adaptive systems, managing at the edge, innovation \& creativity, continuous improvement, total organisational excellence.

7) To what extent does politics play a role in the activities of the Russian oil companies?

Prompts: Russian govt. support, pipeline politics, East Europe economic domination

8) Can you envisage a Russian oil company merging with one of the Western oil majors?

Prompts: TNK proposals, oil industry restructuring, preconditions. 


\section{Appendix 2 Classification of survey participants}

\begin{tabular}{|c|c|c|}
\hline Company & Location & Type \\
\hline \multicolumn{3}{|l|}{ Western Oil Companies } \\
\hline Royal Dutch Shell Group & London & Face to face \\
\hline Shell E\&P Russia & Moscow & Face to face \\
\hline BP Russia & Moscow & Face to face \\
\hline Texaco Russia & Moscow & Face to face \\
\hline Petroleum Advisory Forum & Moscow & Face to face \\
\hline BHP Russia & Moscow & Face to face \\
\hline \multicolumn{3}{|l|}{ Russian Oil Companies } \\
\hline Yukos & Moscow & Face to face \\
\hline Lukoil & Moscow & Telephone \\
\hline TNK & Moscow & Face to face \\
\hline Sibneft & Moscow & Face to face \\
\hline Transneft & Moscow & Face to face \\
\hline \multicolumn{3}{|l|}{ Western Analysts } \\
\hline Chatham House Forum & London & Face to face \\
\hline Arthur Andersen & Moscow & Face to face \\
\hline United Financial Group & Moscow & Face to face \\
\hline Renaissance Capital & London & Face to face \\
\hline Planecon & Washington & Telephone \\
\hline Wood Mackenzie & Edinburgh & Telephone \\
\hline Wood Mackenzie & London & Face to face \\
\hline Financial Times & London & Telephone \\
\hline ABN-AMRO & London & Face to face \\
\hline \multicolumn{3}{|l|}{ Russian Analysts } \\
\hline $\begin{array}{l}\text { International Centre for } \\
\text { Petroleum Business Studies }\end{array}$ & Moscow & Face to face \\
\hline Kortes Research \& Consulting & Moscow & Face to face \\
\hline Troika Dialog & Moscow & Face to face \\
\hline
\end{tabular}

